\title{
The Impact of COVID-19 on Telemedicine Utilization Across Multiple Service Lines in the United States
}

\author{
Jose A. Betancourt *® ${ }^{\circledR}$, Matthew A. Rosenberg $₫$, Ashley Zevallos $₫$, Jon R. Brown $₫$ and \\ Michael Mileski ${ }^{D}$ \\ School of Health Administration, Texas State University, San Marcos, TX 78666, USA; \\ mar401@txstate.edu (M.A.R.); anz11@txstate.edu (A.Z.); jrb296@txstate.edu (J.R.B.); mileski@txstate.edu (M.M.) \\ * Correspondence: jose.a.betancourt@txstate.edu; Tel.: +1-(210)-355-2119
}

Received: 18 August 2020; Accepted: 24 September 2020; Published: 1 October 2020

check for updates

\begin{abstract}
The impact of COVID-19 on the U.S. healthcare industry cannot be overstated. Telemedicine utilization increased overnight as all healthcare providers rushed to implement this delivery model to ensure accessibility and continuity of patient care. Our research objective was to determine measures that were implemented to accommodate community and individual patient needs to afford access to critical services and to maintain safety standards. We analyzed literature since 2016 from two databases using Preferred Reporting Items for Systematic Reviews and Meta-Analyses (PRISMA). We compared observations, themes, service lines addressed, issues identified, and interventions requiring in-person care. From 44 articles published, we identified ten effectiveness themes overall and drew conclusions on service line successes. COVID-19 has caused rapid expansion in telemedicine. Necessary and required changes in access, risk mitigation, the need for social distancing, compliance, cost, and patient satisfaction are a few of the driving factors. This review showcased the healthcare industry's ability to rapidly acclimate and change despite the pervasive spread of COVID-19 throughout the U.S. Although imperfect, unique responses were developed within telemedicine platforms to mitigate disruptions broadly and effectively in care and treatment modalities.
\end{abstract}

Keywords: telemedicine; COVID-19; telehealth; health service lines; pandemic

\section{Introduction}

The use of telemedicine is neither a recent phenomenon nor only found in the United States. One need not look any further than the islands of southern Italy, where a successful telemedicine program has provided great improvements to healthcare delivery to remote areas, bringing with it high-quality care. This telemedicine solution has provided a prompt and qualified health service in the islands while reducing the risks and costs of patient transportation to the mainland [1]. In the United States, an April 1924, Radio News magazine foreshadowed the idea of modern telemedicine through the depiction of a "radio doctor" linked to a patient via sound and a live picture [2]. In 1948, the first known transfer of records through telephone lines occurred in Pennsylvania, when radiologic images were sent across a 24-mile stretch between West Chester and Philadelphia [3]. A decade later, in 1959, medical uses of video communications were initiated at the University of Nebraska, when they used two-way interactive television to transmit information across campus and, in 1964, further established a telemedicine link with the Norfolk State Hospital 112 miles away for group consultations through a closed-circuit, two-television link [2]. A breakthrough in urban emergency medicine was initiated in 1967, between the University of Miami School of Medicine and local fire departments to transmit electrocardiographic rhythms in rescue situations over the radio to Jackson Memorial Hospital [4]. In 1968, a foundational telemedicine project was established involving Boston's Logan Airport, and nearby Massachusetts General Hospital (MGH), in which a medical station at the airport 
was linked via microwave relay to the hospital as a vehicle for providing primary and emergency services to airport staff and travelers. MGH parlayed the success of this effort two years later with a tele-psychiatry link to the Veteran's Administration Hospital in Bedford, MA, that continued operations into the 1980s [5]. One of the earliest joint ventures involving a federal agency was the Space Technology Applied to Rural Papago Advanced Health Care Project (STARPAHC), which was a major initiative begun in 1973, between what was then known as the U.S. Department of Health, Education, and Welfare (now DHHS-Department of Health and Human Services), and involved National Aeronautics and Space Administration (NASA), Lockheed Company, and the U.S. Indian Health Service, in which they began sharing complex medical data, including neurological examinations, videos, stethoscope sounds, and radiological images, to promulgate healthcare services to individuals in distant locales [6].

With the advent of the Internet in the 1990s, telemedicine capabilities proliferated as networks began integrating on a global scale and rendered an easier and cheaper method of building software applications specifically geared towards the asynchronous exchange and storage of clinically-relevant data through mediums such as e-mails, text messaging, and patient portals, and the subsequent synchronous interfacing between provider and patient in real time with live video feeds. Electronic medical records, with the assistance of government incentives, are now ubiquitous and can be engineered to include clinical metrics and user-friendly interfaces to optimize patient care, telemedicine capabilities, and interoperability with vendors, such as laboratory and imaging organizations, for workflow proficiency.

\subsection{Definition of Key Terms}

The Kaiser Family Foundation (2020) considers telehealth and telemedicine to be interchangeable terms and collectively defines them as the "remote provision of healthcare services using technology to exchange information for the diagnosis, treatment, and prevention of disease." [7] Ludwig and Zarbock (2020) delineate Severe Acute Respiratory Syndrome-Associated Coronavirus 2 (SARS-CoV-2) as the novel strain of coronavirus and it is defined as the causal agent of Coronavirus Disease 2019 (COVID-19), these terms may also be interchangeable when referencing the current, ongoing pandemic [8]. DHHS is an acronym for the Department of Health and Human Services, which is the executive branch department of the U.S. Federal Government responsible for providing essential human services to advance the health and well-being of the American people. CMS stands for the Center for Medicare and Medicaid Services, which is an agency embedded within the DHHS that administers the major health programs in the U.S.

\subsection{Rationale}

Table 1 illustrates the transformation in both patient and provider utility of telemedicine both prior to and following the COVID-19 global pandemic. In many instances, the pandemic served as a catalyst accelerating the overall "acceptance" as a viable means of healthcare delivery in the eyes of both patient and provider.

Table 1. Use of telemedicine prior to and following the 2020 COVID-19 pandemic.

\begin{tabular}{clll}
\hline \multicolumn{1}{c}{ User } & Prior to 2020 COVID-19 Pandemic & Following 2020 COVID-19 Pandemic \\
\hline Patients & $\begin{array}{l}\text { 9.6\% of the population used } \\
\text { telemedicine for clinical encounters } \\
74.3 \% \text { noted they either did not have } \\
\text { access or were unaware of telemedicine } \\
\text { options [9]. }\end{array}$ & $\begin{array}{l}\text { Recent study showcased a 14\% surge in } \\
\text { telehealth visits in a given week across a } \\
\text { two-month stretch from mid-March 2020 } \\
\text { to mid-May 2020 [10]. }\end{array}$ \\
\hline Providers & $\begin{array}{l}\text { 18\% of physicians provided a } \\
\text { telemedicine platform for their patients } \\
\text { in 2018 [11]. }\end{array}$ & $\begin{array}{l}\text { Physician practice deployment of } \\
\text { telemedicine usage mushroomed to 48\% } \\
\text { as healthcare providers scrambled to } \\
\text { minimize gaps in care provision amid } \\
\text { the SARS-CoV-2 global pandemic [12]. }\end{array}$ \\
\hline
\end{tabular}


Accommodations in federal, state, and local jurisdictions have facilitated the advancement of telemedicine capabilities through the relaxation of state licensure requirements, DHHS enforcement discretion and penalty waivers of HIPAA (Health Insurance Portability and Accountability Act of 1996)regulations, dissemination of reimbursement allowances for current procedural terminology (CPT) codes, modifiers, and appropriate clinical encounter documentation, and general acceptance and provision of telemedicine utilization to enable the preservation of clinical service delivery [13].

\subsection{Significance}

The swift rise of COVID-19 infection rates upended traditional care delivery models, which overwhelmingly centered around in-person visitations within inpatient and ambulatory care settings. Restrictive measures enacted by state and local officials, such as stay-at-home orders, necessitated the expansion of a nascent platform to accommodate routine and emergent needs for patient populations. Telemedicine can never fully replace face-to-face clinical encounters due to its unconventional and remote nature, particularly as it relates to clinician-assisted care provisions such as physical exams, vaccinations, lab work, imaging, rehabilitative therapies, etc. Despite the absence of hands-on engagement, telemedicine's widespread acceptance and utilization in the wake of the COVID-19 pandemic highlights it as a meaningful and valuable model of care for current and future practice [14].

\subsection{Objective}

Telemedicine utilization erupted on an unprecedented scale as healthcare providers across the U.S. endeavored to stem the deleterious effects of COVID-19. Although the healthcare industry in general was significantly impacted on various levels, we strived to answer this specific question: "What impact has the current COVID-19 pandemic had on the provision of care through telemedicine across unique health service lines that include dermatology, oncology, obstetrics/gynecology, and mental health?"

\section{Methods}

\subsection{Protocol and Registration}

This review used the Preferred Reporting Items for Systematic Reviews and Meta-Analyses (PRISMA) format. The review was not registered, as the registration was not completed prior to analysis per PROSPERO rules. PROSPERO is an international database of prospectively registered systematic reviews in health and social care.

\subsection{Eligibility Criteria}

Studies were deemed germane for this review if articles mentioned the effects of COVID-19 and telemedicine utilization to specific service lines in healthcare to include dermatology, oncology, obstetrics/gynecology, and mental health. These specific service lines were chosen due to the unique nature of their treatment modalities, being often not associated with telemedicine. Mental health was included as telemedicine is used as a normal and expected treatment modality and would provide for excellent comparison to the others chosen. Researchers examined these service lines further due to their differing approaches to patient care and the adaptations that were necessary to obtain desired outcomes from a patient and provider perspective. Articles included were published between 2016 and 2020.

\subsection{Information Sources}

Two databases were queried: The Cumulative Index of Nursing and Allied Health Literature (CINAHL) and PubMed (MEDLINE). Databases were filtered for articles between 2016 and 2020. Database searches occurred during June 2020. 


\subsection{Search}

Reviewers carefully analyzed results from the search across two databases using specific tailored Boolean operators in each. Identical Boolean searches were used in each database. The combination of terms yielded the maximum number of results in both databases. Researchers each reviewed abstracts of articles to determine their relevance to the review and to identify overarching themes.

\subsection{Study Selection}

Search results from two databases were downloaded to a common Excel spreadsheet which was used as a literature matrix. This spreadsheet continued to be used throughout the process to extract data and analyze results. Researchers met weekly to refine search terms, discuss findings, assign workload, and troubleshoot barriers. Within several of these collaborative sessions, consensus meetings were held to establish final agreement on articles germane to our research that would comprise the foundation of our systematic literature review. Author agreement was ultimately measured via calculation of a kappa statistic which was 0.78 , showing substantial agreement among authors.

PRISMA guidelines were used to keep track of the processes of narrowing the initial search results of 52,206 articles to the final selection of 44 sources. Filters were applied to restrict results to a publication date between 2016 and 2020 and the English language. After filtering and removing duplicates, the authors reviewed the abstracts of 52,164 articles. Only those germane to this review, which discussed relationships between COVID-19 and telemedicine surrounding specific service lines, were included in the final selection. All authors collaborated to reach a consensus on the inclusion of articles in the final selection of 44 .

\subsection{Data Collection Process}

Each germane article was reviewed by at least two reviewers who agreed that each article included was germane to the study. Reviewers read through articles twice to ensure that articles were germane and that we were able to make observations relative to the objective of the study. From these observations, a thematic analysis was performed to better organize and make sense of the data. These themes were then used to draw inferences from each of the germane articles and to draw conclusions regarding specific service lines.

\subsection{Data Items}

Via use of the spreadsheet, standard data items were collected: observations, themes, service lines addressed, issues identified in the articles surrounding the use of telemedicine, and any information discussing things requiring in-person care.

\subsection{Risk of Bias in Individual Studies}

SARS-CoV-2 is an evolving global concern and data continues to be collected for literature that is yet to be written and, subsequently, circulated. Resulting from this limited resource availability, what we identified in this review included editorials and other published articles based on best practice recommendations not necessarily applicable to all health service line domains. This may lead to an inherent bias within an article's thesis if it is argued through a lens that is not tested in a practical or real world setting and only speaks to a narrowly defined specialty or primary care arena.

The research group incorporated strategies to minimize the effects of the articles' inherent bias. This included the assignment of article reviews on a randomized basis to which each member had a nearly identical volume of articles to evaluate. Independent analysis was conducted and insights were subsequently shared through a data repository accessible to each member. 


\subsection{Summary Measures}

The review analyzed studies with qualitative, quantitative, mixed methods, editorials, and other published sources, as such the summary measures sought were not consistent. A preferred summary statistic for this study would have been a risk ratio, however, due to the nature of the literature reviewed, this was not possible to measure.

\subsection{Additional Analysis}

During author consensus meetings, a thematic analysis was performed to group observations from the literature into themes. These themes were measured across all literature analyzed and reported as summary statistics in the affinity matrix. The thematic analysis identified ten themes, as reported in Table 2.

\section{Results}

\subsection{Results of Individual Studies and Synthesis of Results}

The impact of the COVID-19 pandemic has created a rapid expansion in telemedicine administration. To reduce the spread of the virus, healthcare providers have engaged social distancing and heightened infection control measures with their patients [15-28]. Telemedicine has been effective through risk mitigation, improved access, convenience, lower cost, and patient satisfaction, of which improved access and risk mitigation were the leading themes [1,13,15-17,20-25,27-44]. The results have also shown a relaxation of licensure requirements, thereby allowing providers to practice across state lines, as well as with HIPAA regulations so devices including smartphones and tablets can be utilized for video conferencing within applications such as Zoom, FaceTime, and Google Hangouts Meet $[13,21,27,32,34,39,41,45,46]$. From the four selected service lines of dermatology, mental health, OB/GYN (obstetrics and gynecology), and oncology, mental health has had the most documented outcomes with the use of telemedicine. This is due in large part because mental health is conversational in nature and the provision of care does not hinge upon in-person interactions. Each service line has found effective uses of telemedicine during the COVID-19 pandemic and, although there are still areas that will require in-person visits for testing, ultrasounds, physical exams, etc., telemedicine is demonstrating that many visits do not require physical attendance and has significantly reduced the total number of patients being seen at a healthcare facility.

Figure 1 illustrates the PRISMA roadmap that comprised our search and selection process. In June 2020, the researchers created a collection of search strings to gather the necessary amount of quality source material and narrow the scope of the search, which led to a sizable return of results. The initial search yielded 267 articles in CINAHL and 51,939 in PubMed, for a cumulative count of 52,206. After applying our limiters, we pared down the final tally to 15 for CINAHL and 29 for PubMed.

Table 2 summarizes the main observations in the articles used and common themes expressed in the investigation that pertained to the search query. The "Outcomes" section did not apply to most of the articles since they are mainly based on opinion pieces; however, articles 15 and 13 were based on studies and the results can be seen in the column. Articles 1-2, 4-5, 8-10, and 16 were used for historical evidence and did not impact the results. 
Table 2. Summary of results.

\begin{tabular}{|c|c|c|c|c|c|}
\hline $\begin{array}{c}\text { First Author, Date, } \\
\text { Reference }\end{array}$ & Title & Publication & Observations & Themes & Service Line Addressed \\
\hline Ludwig, 2020 [8] & $\begin{array}{l}\text { Coronaviruses and } \\
\text { SARS-CoV-2: A Brief } \\
\text { Overview }\end{array}$ & $\begin{array}{l}\text { Anesthesia and } \\
\text { Analgesia }\end{array}$ & $\begin{array}{l}\text { Several cases of pneumonia of unknown } \\
\text { origin were reported from China, which in } \\
\text { early January } 2020 \text { were announced to be } \\
\text { caused by a novel coronavirus. The virus was } \\
\text { later denominated severe acute respiratory } \\
\text { syndrome coronavirus } 2 \text { (SARS-CoV-2) and } \\
\text { defined as the causal agent of Coronavirus } \\
\text { Disease } 2019 \text { (COVID-19) }\end{array}$ & & Infectious Disease \\
\hline J.D. Power, 2019 [9] & $\begin{array}{l}\text { One in } 10 \text { Americans Use } \\
\text { Telehealth, But Nearly } 75 \% \\
\text { Lack Awareness or Access, } \\
\text { J.D. Power Finds }\end{array}$ & PR Newswire & $\begin{array}{l}\text { While } 9.6 \% \text { of Americans have used } \\
\text { telehealth services, nearly three-fourths } \\
\text { (74.3\%) say they either do not have access or } \\
\text { are unaware of telehealth options }\end{array}$ & & Multiple Specialties \\
\hline Eddy, 2020 [10] & $\begin{array}{l}\text { Nearly half of physicians } \\
\text { using telehealth, up from } \\
\text { just 18\% in } 2018\end{array}$ & $\begin{array}{l}\text { Healthcare IT } \\
\text { News }\end{array}$ & $\begin{array}{l}\text { Physicians are changing the patterns of their } \\
\text { practice because of the COVID-19 pandemic, } \\
\text { with nearly half of them using telehealth to } \\
\text { treat patients, up from just } 18 \% \text { in } 2018\end{array}$ & & Multiple Specialties \\
\hline Lehrman, 2020 [13] & $\begin{array}{l}\text { Telemedicine Options: The } \\
\text { COVID-19 pandemic } \\
\text { underscores the role of } \\
\text { remote patient management }\end{array}$ & $\begin{array}{c}\text { Podiatry } \\
\text { Management }\end{array}$ & $\begin{array}{l}\text { - Certain telemedicine services can be } \\
\text { provided year-round } \\
\text { Rapid acceleration of telehealth since the } \\
\text { advent of COVID-19, enforcement discretion } \\
\text { and penalty waivers were issued for HIPAA } \\
\text { violations while providing these services }\end{array}$ & $\begin{array}{l}\text { HIPAA compliance; rapid } \\
\text { expansion }\end{array}$ & Multiple Specialties \\
\hline Gondal, 2020 [14] & $\begin{array}{l}\text { Telemedicine in the time of } \\
\text { COVID-19 Pandemic }\end{array}$ & $\begin{array}{l}\text { Journal of the } \\
\text { College of } \\
\text { Physicians and } \\
\text { Surgeons }\end{array}$ & 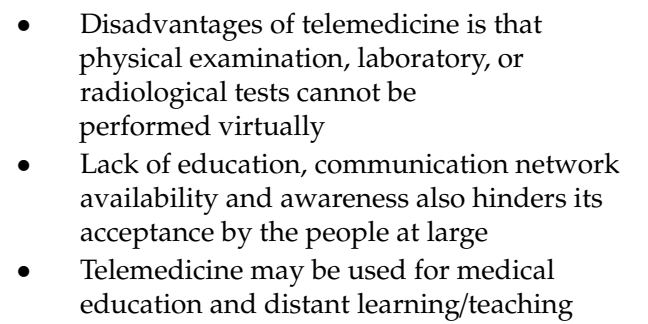 & $\begin{array}{l}\text { "Telemedicine education; risk } \\
\text { mitigation; convenience; } \\
\text { lower cost; social distancing } \\
\text { promotion; improved access" }\end{array}$ & Multiple Specialties \\
\hline
\end{tabular}


Table 2. Cont.

\begin{tabular}{|c|c|c|c|c|c|}
\hline $\begin{array}{c}\text { First Author, Date, } \\
\text { Reference }\end{array}$ & Title & Publication & Observations & Themes & Service Line Addressed \\
\hline Reynolds, 2020 [15] & $\begin{array}{c}\text { Telehealth in Pregnancy } \\
\text { (Editorial) }\end{array}$ & $\begin{array}{c}\text { Lancet Diabetes } \\
\text { and } \\
\text { Endocrinology }\end{array}$ & $\begin{array}{l}\text { - In the rapid implementation of delivery of } \\
\text { remote antenatal care in response to } \\
\text { COVID-19 there remain many uncertainties } \\
\text { There is limited knowledge about women's } \\
\text { views of use of telehealth for monitoring } \\
\text { pregnancy complications, although available } \\
\text { data suggests that women find this to be a } \\
\text { positive experience } \\
\text { There is concern that most of the trials of } \\
\text { telehealth technologies have been done in } \\
\text { highly selected groups and so the findings } \\
\text { might not be applicable to the } \\
\text { wider population } \\
\text { Gestational weight gain and optimal } \\
\text { wellness (GLOW) was a randomized trial of } \\
\text { a weight management intervention delivered } \\
\text { by telephone during a pregnancy with an } \\
\text { aim of reducing gestational weight gain in } \\
\text { women with overweight or obesity }\end{array}$ & $\begin{array}{l}\text { Social distancing; } \\
\text { Self-Isolation; Risk mitigation }\end{array}$ & $\begin{array}{l}\text { OB/GYN } \\
\text { OB/GYN }\end{array}$ \\
\hline Machado, 2020 [16] & $\begin{array}{l}\text { Social Media and } \\
\text { Telemedicine for Oral } \\
\text { Diagnosis and Counselling } \\
\text { in the COVID-19 Era } \\
\text { (Editorial) }\end{array}$ & Oral Oncology & $\begin{array}{l}\text { - } \quad \text { Forward triaging" is possible to screen for } \\
\text { SARS-COV2-2 symptoms and mitigate } \\
\text { community spread } \\
\text { Alternative forms of telemedicine usage (e.g., } \\
\text { text messaging, e-mailing, social media } \\
\text { messaging) are encouraged to avoid long } \\
\text { lines, rule out oral lesions, and obtain } \\
\text { early diagnoses }\end{array}$ & $\begin{array}{l}\text { Social distancing; } \\
\text { Self-Isolation; Risk mitigation }\end{array}$ & Dentistry \\
\hline AHC Media, 2020 [17] & $\begin{array}{l}\text { COVID-19 Shuts Down } \\
\text { Nation; Family Planning } \\
\text { Need Not Stop: Clinics } \\
\text { resort to remote care. }\end{array}$ & Relias Media & $\begin{array}{l}\text { Clinics can phone triage patients before a } \\
\text { scheduled visit to determine whether the } \\
\text { visit can be done by telephone visit, or } \\
\text { synchronous or asynchronous telemedicine } \\
\text { Medicaid and other payers could cover } \\
\text { telehealth services }\end{array}$ & $\begin{array}{l}\text { "Improved access; increased } \\
\text { reimbursements; social } \\
\text { distancing; risk mitigation; } \\
\text { telemedicine education" }\end{array}$ & OB/GYN \\
\hline
\end{tabular}


Table 2. Cont

\begin{tabular}{|c|c|c|c|c|c|}
\hline $\begin{array}{c}\text { First Author, Date, } \\
\text { Reference }\end{array}$ & Title & Publication & Observations & Themes & Service Line Addressed \\
\hline Canady, 2020 [18] & $\begin{array}{l}\text { COVID-19 outbreak } \\
\text { represents a new way of } \\
\text { mental health service } \\
\text { delivery. } \\
\text { (Editorial) }\end{array}$ & $\begin{array}{l}\text { Mental Health } \\
\text { Weekly }\end{array}$ & $\begin{array}{l}\text { - Staff are equipped with iPads and other } \\
\text { - } \quad \text { Staipment necessary to work from home } \\
\text { - } \quad \text { Medications can be left at patient's door }\end{array}$ & $\begin{array}{l}\text { "Telemedicine education; } \\
\text { Social distancing promotion; } \\
\text { improved access" }\end{array}$ & Mental Health \\
\hline Ohannessian, 2020 [19] & $\begin{array}{l}\text { Global Telemedicine } \\
\text { Implementation and } \\
\text { Integration Within Health } \\
\text { Systems to Fight the } \\
\text { COVID-19 Pandemic: A } \\
\text { Call to Action } \\
\text { (Editorial) }\end{array}$ & $\begin{array}{l}\text { JMIR Public } \\
\text { Health and } \\
\text { Surveillance }\end{array}$ & $\begin{array}{l}\text { - Telemedicine shown to be helpful in } \\
\text { previous outbreaks } \\
\text { Two examples of telehealth include (1) } \\
\text { direct-to-consumer telemedicine with private } \\
\text { providers mostly relying on out-of-pocket or } \\
\text { private insurance payment, and (2) free } \\
\text { solutions, mainly from US-based companies } \\
\text { (for example, WhatsApp, Skype, or } \\
\text { Facetime), that may not respect national } \\
\text { health data privacy and security } \\
\text { requirements. A scientific evaluation } \\
\text { framework and dedicated research funds to } \\
\text { describe and assess the impact of } \\
\text { telemedicine during outbreaks }\end{array}$ & $\begin{array}{l}\text { "Improved access; } \\
\text { telemedicine education" }\end{array}$ & Multiple Specialties \\
\hline Lowery, 2020 [20] & $\begin{array}{l}\text { Telehealth: A new frontier } \\
\text { in OB/GYN }\end{array}$ & $\begin{array}{l}\text { Contemporary } \\
\text { OB/GYN }\end{array}$ & $\begin{array}{l}\text { - In utilizing telehealth, the overall healthcare } \\
\text { system benefits from lower costs, less travel, } \\
\text { improved health outcomes, and reduced } \\
\text { emergency room utilization } \\
\text { Barriers include: Licensing and credentialing, } \\
\text { malpractice insurance, and reimbursement } \\
\text { and billing }\end{array}$ & $\begin{array}{l}\text { "Social distancing; } \\
\text { convenience; lower costs; risk } \\
\text { mitigation" }\end{array}$ & OB/GYN \\
\hline AHC Media, 2020 [21] & $\begin{array}{l}\text { COVID-19 Devastates } \\
\text { At-Risk Populations: } \\
\text { Telemedicine could be new } \\
\text { normal }\end{array}$ & Relias Media & $\begin{array}{l}\text { Case managers should focus more on remote } \\
\text { case management, taking the pandemic into } \\
\text { account as they contact and monitor patients }\end{array}$ & $\begin{array}{l}\text { Risk mitigation; social } \\
\text { distancing }\end{array}$ & Multiple Specialties \\
\hline
\end{tabular}


Table 2. Cont.

\begin{tabular}{|c|c|c|c|c|c|}
\hline $\begin{array}{c}\text { First Author, Date, } \\
\text { Reference }\end{array}$ & Title & Publication & Observations & Themes & Service Line Addressed \\
\hline $\begin{array}{c}\text { Romanick-Schmied, } \\
2020 \text { [22] }\end{array}$ & $\begin{array}{c}\text { Telemedicine Maintaining } \\
\text { Quality During Times of } \\
\text { Transition }\end{array}$ & $\begin{array}{l}\text { Nature Reviews } \\
\text { Disease Primers }\end{array}$ & $\begin{array}{l}\text { - The COVID-19 crisis has accelerated the } \\
\text { adoption of telemedicine } \\
\text { Clinics and hospitals have the obligation to } \\
\text { communicate to patients that all possible } \\
\text { means are being taken to prevent } \\
\text { transmission of infection while maintaining } \\
\text { quality in the delivery of care } \\
\text { The advantage of convenience from } \\
\text { conducting a telemedicine visit must be } \\
\text { balanced and weighed against the benefits of } \\
\text { direct human interactions }\end{array}$ & $\begin{array}{l}\text { Improved access; rapid } \\
\text { expansion; social distancing; } \\
\text { convenience; risk mitigation }\end{array}$ & Multiple Specialties \\
\hline Vidal-Alaball, 2020 [23] & $\begin{array}{l}\text { Telemedicine in the Face of } \\
\text { the COVID-19 Pandemic }\end{array}$ & $\begin{array}{l}\text { Atencion } \\
\text { Primaria }\end{array}$ & $\begin{array}{l}\text { Telemedicine connects the convenience, low } \\
\text { cost, and ready accessibility of health-related } \\
\text { information and communication using the } \\
\text { Internet and associated technologies } \\
\text { Telemedicine during the coronavirus } \\
\text { epidemic has been the doctors' first line of } \\
\text { defense to slow the spread of the coronavirus, } \\
\text { keeping social distancing and providing } \\
\text { services by phone or videoconferencing }\end{array}$ & $\begin{array}{l}\text { Improved access; rapid } \\
\text { expansion; social distancing; } \\
\text { lower cost; convenience }\end{array}$ & Multiple Specialties \\
\hline Wosik, 2020 [24] & $\begin{array}{c}\text { Telehealth transformation: } \\
\text { COVID-19 and the rise of } \\
\text { virtual care }\end{array}$ & $\begin{array}{l}\text { Journal of the } \\
\text { American } \\
\text { Medical } \\
\text { Informatics } \\
\text { Association }\end{array}$ & $\begin{array}{l}\text { - The pandemic has catalyzed rapid adoption } \\
\text { of telehealth, or the entire spectrum of } \\
\text { activities used to deliver care at a distance } \\
\text { Healthcare enterprises may already have in } \\
\text { place technologies that can be employed to } \\
\text { accomplish telehealth }\end{array}$ & $\begin{array}{l}\text { Rapid expansion; social } \\
\text { distancing }\end{array}$ & Multiple Specialties \\
\hline Bashshur, 2020 [25] & $\begin{array}{l}\text { Telemedicine and the } \\
\text { COVID-19 Pandemic, } \\
\text { Lessons for the Future } \\
\text { (Editorial) }\end{array}$ & $\begin{array}{l}\text { Telemedicine } \\
\text { Journal and } \\
\text { e-health }\end{array}$ & $\begin{array}{l}\text { - Conversion to telemedicine demonstrates its } \\
\text { utility as an effective tool for social distancing } \\
\text { A sizeable proportion of outpatient visits can } \\
\text { be clinically managed effectively from } \\
\text { a distance } \\
\text { - Government has relaxed all restrictive } \\
\text { regulations for telemedicine deployment. } \\
\text { The necessary logistics can be } \\
\text { developed promptly }\end{array}$ & $\begin{array}{l}\text { "Improved access; increased } \\
\text { reimbursement; rapid } \\
\text { expansion; social distancing; } \\
\text { convenience; lower cost; risk } \\
\text { mitigation; telemedicine } \\
\text { education; relaxed } \\
\text { regulations" }\end{array}$ & Multiple Specialties \\
\hline
\end{tabular}


Table 2. Cont

\begin{tabular}{|c|c|c|c|c|c|}
\hline $\begin{array}{l}\text { First Author, Date, } \\
\text { Reference }\end{array}$ & Title & Publication & Observations & Themes & Service Line Addressed \\
\hline Spinelli, 2020 [26] & $\begin{array}{l}\text { COVID-19 Pandemic: } \\
\text { Perspectives on an } \\
\text { Unfolding Crisis }\end{array}$ & $\begin{array}{l}\text { British Journal of } \\
\text { Surgery }\end{array}$ & $\begin{array}{l}\text { Telemedicine may reduce the need for } \\
\text { physical attendance in outpatient clinics, } \\
\text { minimizing contact exposure } \\
\text { Surgical staff and the available units have } \\
\text { been modified to balance service provision, } \\
\text { reducing infection risk, and specialist care }\end{array}$ & $\begin{array}{l}\text { Risk mitigation; social } \\
\text { distancing }\end{array}$ & Multiple Specialties \\
\hline Mann, 2020 [27] & $\begin{array}{l}\text { COVID-19 Transforms } \\
\text { Health Care Through } \\
\text { Telemedicine: Evidence } \\
\text { From the Field }\end{array}$ & $\begin{array}{l}\text { Journal of the } \\
\text { American } \\
\text { Medical } \\
\text { Informatics } \\
\text { Association }\end{array}$ & $\begin{array}{l}\text { - U.S. insurers have quickly expanded } \\
\text { coverage to include all telemedicine } \\
\text { visit types } \\
\text { The U.S. Department of Health \& Human } \\
\text { Services (HHS) waived enforcement of } \\
\text { HIPAA regulations to allow the use of } \\
\text { consumer audio and video communication } \\
\text { for telemedicine visits }\end{array}$ & $\begin{array}{l}\text { HIPAA compliance; increased } \\
\text { reimbursement; rapid } \\
\text { expansion; social distancing; } \\
\text { patient satisfaction; risk } \\
\text { mitigation; telemedicine } \\
\text { education }\end{array}$ & Multiple Specialties \\
\hline Aziz, 2020 [28] & $\begin{array}{l}\text { Telehealth for High-Risk } \\
\text { Pregnancies in the Setting of } \\
\text { the COVID-19 Pandemic }\end{array}$ & $\begin{array}{l}\text { American } \\
\text { Journal of } \\
\text { Perinatology }\end{array}$ & $\begin{array}{l}\text { - Telehealth for pre-natal care is feasible } \\
\text { - Tailored regimens for increased surveillance } \\
\text { and counseling are permissible } \\
\text { - Certain high-risk pregnancies may require } \\
\text { increased frequency of in-person encounters }\end{array}$ & $\begin{array}{l}\text { Mitigate risk for COVID-19 } \\
\text { exposure; minimize patient } \\
\text { travel }\end{array}$ & OB/GYN \\
\hline Zhou, 2020 [29] & $\begin{array}{l}\text { The Role of Telehealth in } \\
\text { Reducing the Mental Health } \\
\text { Burden from COVID-19 } \\
\text { (Editorial) }\end{array}$ & $\begin{array}{l}\text { Telemedicine } \\
\text { Journal and } \\
\text { e-health }\end{array}$ & $\begin{array}{l}\text { - Tele-mental health services are feasible, } \\
\text { appropriate, and perfectly suited to the } \\
\text { current pandemic environment } \\
\text { Simple communication methods (e.g., } \\
\text { e-mails, texts, etc.) should be used } \\
\text { more extensively }\end{array}$ & $\begin{array}{l}\text { Increased access; infection } \\
\text { risk mitigation }\end{array}$ & Mental Health \\
\hline Freeman, 2020 [30] & $\begin{array}{l}\text { COVID-19 From a } \\
\text { Psychiatry Perspective: } \\
\text { Meeting the Challenges }\end{array}$ & $\begin{array}{l}\text { The Journal of } \\
\text { Clinical } \\
\text { Psychiatry }\end{array}$ & $\begin{array}{l}\text { - We have seen telemedicine set up at record } \\
\text { speed to meet the needs of patients } \\
\text { - Regulatory barriers to reach many patients } \\
\text { were brought down almost overnight }\end{array}$ & $\begin{array}{l}\text { Regulatory barrier removal, } \\
\text { rapid expansion, improved } \\
\text { access }\end{array}$ & Mental Health \\
\hline
\end{tabular}


Table 2. Cont

\begin{tabular}{|c|c|c|c|c|c|}
\hline $\begin{array}{c}\text { First Author, Date, } \\
\text { Reference }\end{array}$ & Title & Publication & Observations & Themes & Service Line Addressed \\
\hline AHC Media, 2020 [31] & $\begin{array}{l}\text { Shift to Telehealth Could } \\
\text { Remain Trend After } \\
\text { COVID-19: Reproductive } \\
\text { health remains priority. }\end{array}$ & Relias Media & $\begin{array}{l}\text { - Clinics have quickly shifted to phone } \\
\text { screenings and videoconferences } \\
\text { - No penalties for Health Insurance Portability } \\
\text { and Accountability Act } \\
\text { (HIPAA) noncompliance } \\
\text { - } \quad \begin{array}{l}\text { Positive experience from patients } \\
\text { and providers }\end{array} \\
\text { - Medicare waiving copays and deductibles }\end{array}$ & $\begin{array}{l}\text { HIPAA compliance; lower } \\
\text { costs; patient satisfaction }\end{array}$ & OB/GYN \\
\hline Knoph, 2020 [32] & $\begin{array}{c}\text { Telepsychiatry Coming Into } \\
\text { Its Own With COVID-19 } \\
\text { (Editorial) }\end{array}$ & $\begin{array}{l}\text { Brown } \\
\text { University Child } \\
\text { and Adolescent } \\
\text { Pharmacology } \\
\text { Update }\end{array}$ & $\begin{array}{l}\text { - Children find tele-psychiatry easy to use } \\
\text { since they are used to technology } \\
\text { - Children with anxiety or trauma feel more } \\
\text { comfortable with tele-psychiatry } \\
\text { - Increase in patient and provider } \\
\text { satisfaction rate }\end{array}$ & $\begin{array}{l}\text { "Patient satisfaction; } \\
\text { reimbursement; improved } \\
\text { access" }\end{array}$ & Mental Health \\
\hline Parikh, 2020 [33] & $\begin{array}{l}\text { Cardio-Oncology Care In } \\
\text { the Time of COVID-19 and } \\
\text { the Role of Telehealth }\end{array}$ & $\begin{array}{c}\text { JACC } \\
\text { CardioOncology }\end{array}$ & $\begin{array}{ll}\text { - } & \text { Many cardio-oncology visits cannot be } \\
\text { safely deferred } \\
\text { - } \quad \text { Officials have approved interstate licensing } \\
\text { - } \quad \text { Patients can be monitored remotely }\end{array}$ & $\begin{array}{l}\text { "Improved access; risk } \\
\text { mitigation; convenience" }\end{array}$ & Oncology \\
\hline Rodler, 2020 [34] & $\begin{array}{l}\text { Lessons from the } \\
\text { coronavirus disease } 2019 \\
\text { pandemic: Will virtual } \\
\text { patient management } \\
\text { reshape uro-oncology in } \\
\text { Germany? }\end{array}$ & $\begin{array}{l}\text { European } \\
\text { Journal of } \\
\text { Cancer }\end{array}$ & $\begin{array}{l}\text { - Patients with exposure to COVID follow up } \\
\text { via phone or e-mail and asked to write a } \\
\text { symptom diary } \\
\text { - Virtual management and reductions in } \\
\text { frequency of visits are feasible }\end{array}$ & Risk mitigation & Oncology \\
\hline Steingass, 2020 [35] & $\begin{array}{l}\text { Telehealth Triage and } \\
\text { Oncology Nursing Practice }\end{array}$ & $\begin{array}{l}\text { Seminars in } \\
\text { Oncology } \\
\text { Nursing }\end{array}$ & $\begin{array}{l}\text { - Oncology nurses must understand various } \\
\text { methods of telehealth and how to establish } \\
\text { and work in the new environment } \\
\text { Organization must ensure that the telehealth } \\
\text { program is focused on meeting the clinical } \\
\text { needs of the defined patient population } \\
\text { Identifying ways to improve gaps in care } \\
\text { coordination or management will help } \\
\text { determine what types of telehealth } \\
\text { encounters must be deployed within } \\
\text { the organization }\end{array}$ & Telemedicine education & Oncology \\
\hline
\end{tabular}


Table 2. Cont

\begin{tabular}{|c|c|c|c|c|c|}
\hline $\begin{array}{l}\text { First Author, Date, } \\
\text { Reference }\end{array}$ & Title & Publication & Observations & Themes & Service Line Addressed \\
\hline AHC Media, 2020 [36] & $\begin{array}{l}\text { Hospitals Use Telemedicine } \\
\text { to Limit Exposures, } \\
\text { Preserve Personal Protective } \\
\text { Equipment (PPE), Guide } \\
\text { Patients to Right Setting }\end{array}$ & Relias Media & $\begin{array}{l}\text { - Centers for Medicare \& Medicaid Services } \\
\text { (CMS) pledges penalties will not be imposed } \\
\text { on providers who use telehealth in ways that } \\
\text { are not compliant with HIPAA requirements } \\
\text { Clinicians can bill for telemedicine visits with } \\
\text { reimbursement rates on par with } \\
\text { in-person visits }\end{array}$ & $\begin{array}{c}\text { “Improved access; HIPAA } \\
\text { compliance; increased } \\
\text { reimbursement; rapid } \\
\text { expansion" }\end{array}$ & Multiple Specialties \\
\hline Bokolo, 2020 [37] & $\begin{array}{l}\text { Use of Telemedicine and } \\
\text { Virtual Care for Remote } \\
\text { Treatment in Response to } \\
\text { COVID-19 Pandemic }\end{array}$ & $\begin{array}{c}\text { Journal of } \\
\text { Medical Systems }\end{array}$ & $\begin{array}{l}\text { - Hospitals can improve the efficiency of the } \\
\text { medical system by replacing a proportion of } \\
\text { physical treatments with digital technologies } \\
\text { CMS now allow medical-care providers to } \\
\text { utilize devices such as smartphones and } \\
\text { electronic devices to treat patients } \\
\text { The US drug enforcement administration is } \\
\text { also allowing medical practitioners to } \\
\text { prescribe of medication after patient } \\
\text { diagnosis and assessment conducted } \\
\text { via telemedicine }\end{array}$ & $\begin{array}{l}\text { Rapid expansion; risk } \\
\text { mitigation }\end{array}$ & Multiple Specialties \\
\hline Portnoy, 2020 [38] & $\begin{array}{l}\text { Telemedicine in the Era of } \\
\text { COVID-19 } \\
\text { (Editorial) }\end{array}$ & $\begin{array}{l}\text { The Journal of } \\
\text { Allergy and } \\
\text { Clinical } \\
\text { Immunology }\end{array}$ & $\begin{array}{l}\text { - Telemedicine (TM) has the potential to help } \\
\text { by permitting mildly ill patients to get the } \\
\text { supportive care they need while minimizing } \\
\text { their exposure to other acutely ill patients } \\
\text { - Nearly all health plans and large employers } \\
\text { offer some form of coverage for TM services } \\
\text { - Patients may be unaware that they have TM } \\
\text { as an option and do not know how to } \\
\text { access it } \\
\text { For routine telemedicine video visits, many } \\
\text { of the requirements have been waived } \\
\text { during this time }\end{array}$ & $\begin{array}{c}\text { “Risk mitigation; improved } \\
\text { access; increased } \\
\text { reimbursement; HIPAA } \\
\text { compliance" }\end{array}$ & Multiple Specialties \\
\hline Contreras, 2020 [39] & $\begin{array}{l}\text { Telemedicine: } \\
\text { Patient-Provider Clinical } \\
\text { Engagement During the } \\
\text { COVID-19 Pandemic and } \\
\text { Beyond }\end{array}$ & $\begin{array}{l}\text { Journal of } \\
\text { Gastrointestinal } \\
\text { Surgery }\end{array}$ & $\begin{array}{l}\text { In response to the COVID-19 pandemic, } \\
\text { federal agencies have promoted telehealth } \\
\text { both through regulatory relaxation and } \\
\text { increased funding } \\
\text { Telemedicine can facilitate an international } \\
\text { reach to patients across the world }\end{array}$ & $\begin{array}{l}\text { Increased reimbursement; } \\
\text { relaxed regulations; improved } \\
\text { access }\end{array}$ & Multiple Specialties \\
\hline
\end{tabular}


Table 2. Cont

\begin{tabular}{|c|c|c|c|c|c|}
\hline $\begin{array}{l}\text { First Author, Date, } \\
\text { Reference }\end{array}$ & Title & Publication & Observations & Themes & Service Line Addressed \\
\hline Boxer, 2019 [40] & $\begin{array}{l}\text { Advantages and utilization } \\
\text { of telemedicine }\end{array}$ & mHealth & $\begin{array}{l}\text { Authors explore the various reasons for } \\
\text { telemedicine utilization and offer } \\
\text { suggestions to increase the delivery of } \\
\text { high-quality telemedicine services; } \\
\text { telemedicine is, at present, a primary means } \\
\text { of expanding care to those with limited } \\
\text { access to physicians. Some states have } \\
\text { introduced cross-state licensing } \\
\text { Economics is another barrier to the } \\
\text { expansion of telemedicine. Congressional } \\
\text { Telehealth Caucus reintroduced several bills } \\
\text { aimed at addressing Medicare barriers } \\
\text { impeding telemedicine efforts, these include } \\
\text { an expansion of the scope of reimbursed } \\
\text { services along with redefining } \\
\text { rural qualifications }\end{array}$ & $\begin{array}{l}\text { Improved access; relaxed } \\
\text { regulations; increased } \\
\text { reimbursement }\end{array}$ & Multiple Specialties \\
\hline Jobes, 2020 [41] & $\begin{array}{l}\text { The COVID-19 pandemic } \\
\text { and treating suicidal risk: } \\
\text { The telepsychotherapy use } \\
\text { of CAMS }\end{array}$ & $\begin{array}{c}\text { Journal of } \\
\text { Psychotherapy }\end{array}$ & $\begin{array}{l}\text { - The pandemic has thus sparked a sudden } \\
\text { interest in providing mental health services } \\
\text { via tele-psychotherapy } \\
\text { The coronavirus pandemic now poses all new } \\
\text { approval concerns about the routine practice } \\
\text { of having an acutely suicidal patient go to an } \\
\text { emergency department and/or admitting } \\
\text { such patients to an inpatient psychiatric unit }\end{array}$ & Telemedicine education & Mental Health \\
\hline Elkaddoum, 2020 [42] & $\begin{array}{l}\text { Telemedicine for cancer } \\
\text { patients during COVID-19 } \\
\text { pandemic: between threats } \\
\text { and opportunities }\end{array}$ & Future Oncology & $\begin{array}{l}\text { - It was clearly recommended to switch to } \\
\text { telemedicine as much as possible for patients } \\
\text { who present new symptoms or side effects, } \\
\text { despite being considered high- to } \\
\text { medium-priority patients } \\
\text { This approach minimizes the need for } \\
\text { individuals to visit healthcare facilities, } \\
\text { leading to a lesser consumption of PPE by } \\
\text { the patients and the doctors }\end{array}$ & $\begin{array}{l}\text { Improved access; risk } \\
\text { mitigation }\end{array}$ & Oncology \\
\hline
\end{tabular}


Table 2. Cont.

\begin{tabular}{|c|c|c|c|c|c|}
\hline $\begin{array}{l}\text { First Author, Date, } \\
\text { Reference }\end{array}$ & Title & Publication & Observations & Themes & Service Line Addressed \\
\hline Trinidad, 2020 [43] & $\begin{array}{c}\text { Telemedicine for inpatient } \\
\text { dermatology consultations } \\
\text { in response to the } \\
\text { COVID-19 pandemic } \\
\text { (Editorial) }\end{array}$ & $\begin{array}{l}\text { Journal of the } \\
\text { American } \\
\text { Academy of } \\
\text { Dermatology }\end{array}$ & $\begin{array}{l}\text { Dermatologists are poised to use } \\
\text { tele-dermatology to increase access to } \\
\text { dermatologic care for hospitalized patients, } \\
\text { reduce the risk of infection of patients, } \\
\text { trainees, and staff, and reduce the use of } \\
\text { precious resources such as personal } \\
\text { protective equipment and medical supplies }\end{array}$ & $\begin{array}{l}\text { Improved access; risk } \\
\text { mitigation }\end{array}$ & Dermatology \\
\hline Lovett, 2020 [44] & $\begin{array}{l}\text { Incorporating Telemedicine } \\
\text { as part of COVID-19 } \\
\text { Outbreak Response Systems }\end{array}$ & $\begin{array}{l}\text { The American } \\
\text { Journal of } \\
\text { Managed Care }\end{array}$ & $\begin{array}{l}\text { - } \quad \text { Telemedicine platforms are ideal for } \\
\text { managing several challenges facing } \\
\text { healthcare systems in response to global } \\
\text { infectious disease outbreaks } \\
\text { Implementing telemedicine systems focuses } \\
\text { on addressing the needs of low-acuity } \\
\text { patients with disease exposure concern } \\
\text { State and federal laws and regulations have } \\
\text { evolved in recent years, months, and days to } \\
\text { facilitate greater reimbursement for and } \\
\text { adoption of various telemedicine models. } \\
\text { State, federal, and international laws and } \\
\text { regulations have been significantly relaxed to } \\
\text { promote greater adoption and use of } \\
\text { telemedicine and other digital health } \\
\text { technologies to deliver clinical services }\end{array}$ & $\begin{array}{l}\text { "Improved access; increased } \\
\text { reimbursement; rapid } \\
\text { expansion; risk mitigation, } \\
\text { relaxed regulations" }\end{array}$ & Multiple Specialties \\
\hline Goldberg, 2020 [45] & $\begin{array}{l}\text { Tele-dermatology and } \\
\text { HIPAA compliance in the } \\
\text { era of COVID-19. }\end{array}$ & $\begin{array}{l}\text { Dermatology } \\
\text { Times }\end{array}$ & $\begin{array}{l}\text { - There exist Liability issues under the HIPAA } \\
\text { that physicians and dermatologists will be } \\
\text { facing when using telemedicine or } \\
\text { tele-dermatology to communicate with } \\
\text { patients amidst the coronavirus pandemic } \\
\text { These include being subjected to disciplinary } \\
\text { action if they exceed the license granted by } \\
\text { his/her state, and negligence liability for } \\
\text { doctors providing the telemedicine service in } \\
\text { a state different from where the patient lives } \\
\text { E-health and Telemedicine are great tools that } \\
\text { can be utilized within the healthcare industry } \\
\text { especially during the COVID pandemic }\end{array}$ & HIPAA compliance & Dermatology \\
\hline
\end{tabular}


Table 2. Cont

\begin{tabular}{|c|c|c|c|c|c|}
\hline $\begin{array}{l}\text { First Author, Date, } \\
\text { Reference }\end{array}$ & Title & Publication & Observations & Themes & Service Line Addressed \\
\hline Prasad, 2020 [46] & $\begin{array}{l}\text { Optimizing Your } \\
\text { Telemedicine Visit During } \\
\text { the COVID-19 Pandemic: } \\
\text { Practice Guidelines for } \\
\text { Patients With Head and } \\
\text { Neck Cancer }\end{array}$ & Head and Neck & $\begin{array}{l}\text { Guidelines are necessary to set patient } \\
\text { expectations and to also ensure both } \\
\text { providers and patients are appropriately } \\
\text { educated on telemedicine } \\
\text { platform functionality }\end{array}$ & $\begin{array}{c}\text { Patient/Provider Telemedicine } \\
\text { Education }\end{array}$ & Oncology \\
\hline Badeli, 2020 [47] & $\begin{array}{l}\text { Utilizing Telemedicine for } \\
\text { Managing COVID-19 }\end{array}$ & $\begin{array}{l}\text { Journal of } \\
\text { Pediatric } \\
\text { Nephrology }\end{array}$ & $\begin{array}{l}\text { - The integration of eHealth for patients with } \\
\text { COVID-19 is indicated as a global emergency } \\
\text { to reduce virus transmission } \\
\text { Telemedicine provides a promising solution } \\
\text { to provide quality care while reducing risk of } \\
\text { transmissions to both other patients and } \\
\text { healthcare providers } \\
\text { Previous investigations on the effect of this } \\
\text { method on outpatients with chronic stable } \\
\text { diseases showed its cost effectiveness, high } \\
\text { satisfaction among patients and caregivers, } \\
\text { and no significant difference in service use or } \\
\text { disease progression, it is not an appropriate } \\
\text { method for all clinical situations. Not } \\
\text { appropriate for patients with severe diseases. } \\
\text { As Nephrology consultation needs } \\
\text { commonly laboratory assessments, video } \\
\text { consultation can help patients to receive } \\
\text { disease education and explanation of } \\
\text { treatment choices }\end{array}$ & $\begin{array}{l}\text { "Improved access; social } \\
\text { distancing; lower cost; patient } \\
\text { satisfaction" }\end{array}$ & Oncology \\
\hline Cosic, 2020 [48] & $\begin{array}{l}\text { Impact of Human Disasters } \\
\text { and COVID-19 Pandemic } \\
\text { on Mental Health: Potential } \\
\text { of Digital Psychiatry }\end{array}$ & $\begin{array}{l}\text { Psychiatria } \\
\text { Danubina }\end{array}$ & $\begin{array}{l}\text { - Comprehensive approach based on digital } \\
\text { psychiatry is proposed to address the lack of } \\
\text { access to psychiatric services, which includes } \\
\text { artificial intelligence, tele-psychiatry and an } \\
\text { array of new technologies, like } \\
\text { internet-based computer-aided mental health } \\
\text { tools and services }\end{array}$ & $\begin{array}{l}\text { Improved access; } \\
\text { telemedicine education }\end{array}$ & Mental Health \\
\hline
\end{tabular}




\section{Identification}

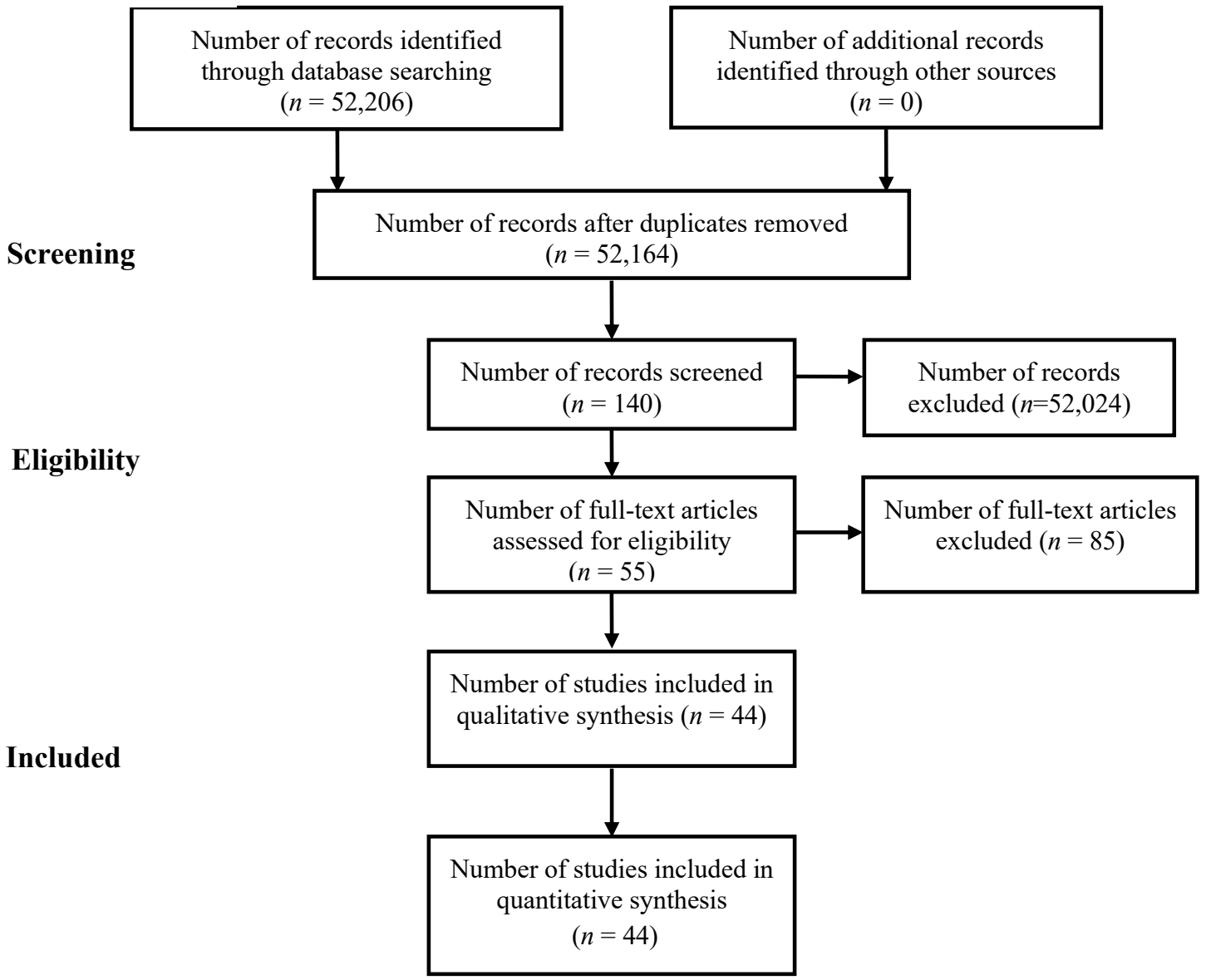

Figure 1. Preferred reporting items for systematic reviews and meta-analyses flow diagram of the literature search and selection process.

\subsection{Additional Analysis}

Table 3 is an affinity matrix that displays the effectiveness themes extracted from our research and the specific articles in which they were found. The total number of occurrences were summed and divided by the total volume of articles $(n)$ to create the probability of occurrence. It should be noted these themes are meant to demonstrate a measure of mutual similarity and do not equate to a hierarchy of importance.

Table 3. Affinity matrix.

\begin{tabular}{cccc}
\hline Effectiveness Themes & Article Citation Number & $\begin{array}{c}\text { Incidence of } \\
\text { Occurrence }(\boldsymbol{n}=\mathbf{4 3})\end{array}$ & $\begin{array}{c}\text { Probability } \\
\text { of Occurrence }\end{array}$ \\
\hline Improved Access & {$[1,13,17,20,23-25,29-33,35,37-42,44,47]$} & 21 & $48 \%$ \\
\hline Risk Mitigation & {$[1,13,15-17,20-23,25,27-29,33,34,36,37,39,43]$} & 19 & $43 \%$ \\
\hline Social Distancing Promotion & {$[13,15-17,20,21,23,24,27,35-37,41,44]$} & 14 & $32 \%$ \\
\hline $\begin{array}{c}\text { Rapid Telemedicine } \\
\text { Expansion }\end{array}$ & {$[13,22-26,30,32,33,35,37,44]$} & 12 & $27 \%$ \\
\hline $\begin{array}{c}\text { HIPAA Compliance/Relaxed } \\
\text { Regulations }\end{array}$ & {$[13,25,26,30,31,37-40,47,48]$} & 11 & $25 \%$ \\
\hline $\begin{array}{c}\text { Telemedicine Education } \\
\text { Increased or Similar } \\
\text { Reimbursements }\end{array}$ & {$[13,17,19,20,35,37,38,44-46]$} & 10 & $23 \%$ \\
\hline
\end{tabular}


Table 3. Cont

\begin{tabular}{cccc}
\hline Effectiveness Themes & Article Citation Number & $\begin{array}{c}\text { Incidence of } \\
\text { Occurrence }(\boldsymbol{n}=\mathbf{4 3})\end{array}$ & $\begin{array}{c}\text { Probability } \\
\text { of Occurrence }\end{array}$ \\
\hline Convenience & {$[13,20,21,23,24,31,33]$} & 7 & $16 \%$ \\
\hline Lower Cost & {$[13,20,21,24,38,41]$} & 6 & $14 \%$ \\
\hline Patient Satisfaction & {$[31,32,37,41]$} & 4 & $9 \%$ \\
\hline
\end{tabular}

Table 4 is a chart that outlines some of the implementation successes of telemedicine utilization on the health service lines we selected for this systematic literature review in the wake of COVID-19 proliferation. Each service line experiences diverse workflow requirements and care provision criteria, which translated to varying levels of positive outcomes resulting from the accelerated transition to virtual medicine.

Table 4. Service line successes through telemedicine utilization during the COVID-19 pandemic.

\begin{tabular}{|c|c|}
\hline Service Line & Implementation Successes \\
\hline Dermatology & $\begin{array}{c}\text { Rapid diagnosis and treatment, increased access, reduced risk of infection, minimization of } \\
\text { PPE and medical supply utilization, addressed health care disparities for underserved and } \\
\text { rural populations. }\end{array}$ \\
\hline OB/GYN & $\begin{array}{l}\text { A typical virtual visit includes the pregnant woman utilizing home monitoring supplies to } \\
\text { track measures such as fetal heart rate, maternal blood pressure, and fundal height. } \\
\text { Specialists are able to view ultrasounds and other examinations through available } \\
\text { technology, often in real-time. Home monitoring is also possible for certain high-risk } \\
\text { conditions. Clinics quickly shifted to phone screening and initial consultations, as well as } \\
\text { videoconferences with patients. Some clinics provided contraception renewals and new } \\
\text { prescriptions through telemedicine. From a family planning perspective, telehealth visits } \\
\text { have been a positive experience that both patients and providers favor. Clinics can phone } \\
\text { triage patients before a scheduled visit to determine whether the visit can be done by } \\
\text { telephone visit, or synchronous or asynchronous telemedicine. GLOW was a randomized } \\
\text { trial of a weight management intervention delivered by telephone during a pregnancy } \\
\text { with an aim of reducing gestational weight gain in women with overweight or } \\
\text { obesity-goals of implementation were to consolidate in-person prenatal screening, } \\
\text { surveillance, and examinations into fewer in-person visits while maintaining patient access } \\
\text { to ongoing antenatal care and subspecialty consultations via telehealth virtual visits. }\end{array}$ \\
\hline Oncology & $\begin{array}{l}\text { Less consumption of PPE, can ensure patients are adhering to given recommendations, } \\
\text { patients can address new symptoms, fears, or questions with providers. Cardio-oncology } \\
\text { patients can be evaluated regularly, e.g., blood pressure readings, weight scales, or Cardio } \\
\text { Micro Electro Mechanical System (CardioMEMS). Strict quarantine observation, reduced } \\
\text { clinic visits, survivorship care planning, patient education. }\end{array}$ \\
\hline Mental Health & $\begin{array}{l}\text { Supporting both physical and psychosocial needs irrespective of geographic locations. } \\
\text { Children with anxiety or significant trauma feel more comfortable than they would with } \\
\text { in-person therapy. In response to the sudden need to provide tele-psychotherapy services, } \\
\text { organizations quickly developed and offered free resources, clinical guidance, and } \\
\text { synchronous and asynchronous access to online presentations to thousands of mental } \\
\text { health providers around the world. Prescriptions can now be made (but not for other } \\
\text { controlled substances, such as ADHD medications) after a thorough assessment through a } \\
\text { live interactive video. Collaborative Assessment and Management of Suicidality (CAMS) } \\
\text { protocols were created to provide support, guidance, and resources. Increase in patient } \\
\text { and provider satisfaction rates. }\end{array}$ \\
\hline
\end{tabular}

\section{Discussion}

\subsection{Summary of Evidence}

Telemedicine acts as a bridge between patient and provider in separate locations in one of the safest manners possible. The sweeping prevalence of COVID-19 within the U.S. forced the healthcare 
industry to reimagine their models of care and how they provisioned services to new and established patients that directly resulted in the explosion of telemedicine utilization. We narrowed our focus to address four specific service lines with unique requirements to examine how disruptions to continuity of care could be mitigated, which required sophisticated, timely course corrections to meet individual and community needs for urgent and non-urgent encounters.

A detailed analysis of our research resulted in the emergence of an array of themes that were commonplace within the selected service lines. The leading indicators for telemedicine utilization expansion were efforts to increase access to patients, deploy social distancing measures, and attempt to mitigate the risks of exposure to other patients. By virtue of the telemedicine platform, patients were less encumbered by geographic distance, particularly those residing in rural areas, as well as physical limitations, and transportation concerns, thereby allowing them to engage their providers outside of the clinical space. In effect, this increased access enabled a dual track of social distancing allowance and risk mitigation that precluded concerns of having to avoid contact with other patrons in lobbies, hallways, exam rooms, restrooms, etc., where an exchange of microbes is commonplace.

Telemedicine provides a more convenient method of care provision as patients can obtain services within the confines of their preferred location whether its their home, office, car, etc. This reduces the burdens of travel time, missed work and/or school, and opportunity and monestary costs.

Two of the more notable barriers to widespread telemedicine adoption prior to COVID-19 dispersion were issues related to HIPAA compliance in the context of privacy concerns with secure communication lines and data sharing, burdensome regulations, interstate licensure requirements, and reimbursement disparities amongst U.S. insurers who rendered payouts not on-par with in-person visits. These obstacles were relaxed by CMS, DHHS, and public and commercial payers to accommodate a new care provision reality. Even though telemedicine was marginally utilized prior to the spread of COVID-19, additional training and education for patients and providers are necessary to adapt to changing protocols, assessment criteria, and basic understanding of telemedicine functionality $[13,17,19,20,35,37,38,42,45,46]$. Widespread infection rates and spikes in hospitalizations resulting from COVID-19 proliferation spurred the rapid adoption of telemedicine utilization virtually overnight. While this was aided and abetted by local stay-at-home orders and the broader public fears of acquiring the disease, healthcare providers realized the need to still provide critical services to their patient populations and understood telemedicine platforms were the perfect vehicles to rise to the occasion. A direct result of this expansion was the need to fully educate providers, clinical/administrative support staff, and patients in how to effectively utilize this new model of care provision. This included webinars and online tutorials, quick reference guides, phone consultations, and do-it-yourself learning. Lastly, patient satisfaction levels were not widely discussed in the literature, but there were indications they were generally satisfied with their telemedicine experience, provided they could connect with their providers in the virtual domain and achieve desirable outcomes from the encounters $[7,9,27,31]$. While many patients prefer to be with their providers in-person for face-to-face encounters, and likewise from the provider perspective, telemedicine was viewed as a suitable replacement considering the present COVID-19 environment.

\subsection{Limitations}

We encountered a series of limitations during our research: (1) Recent phenomenon of COVID-19 dramatically restricts our research timeline and availability of pertinent articles due to novel, mercurial circumstances. In the two-month span of our study, additional articles were likely published after our initial capture that were not employed in our final analysis. (2) With protective measures ebbing and flowing in real time in response to the changing tides of COVID-19's effects, healthcare services may reinstitute in-person services (i.e., elective surgeries, minor procedures, physical exams, etc.) or scale them back as conditions on the ground dictate in any given locality; these fluctuations, in turn, will cause a see-saw effect of telemedicine utilization. (3) Selection bias-we attempted to control against this variable through a rigorous vetting process via group consensus. (4) Publication bias-our searches were narrowly conducted across only two databases and did not include any forms of grey 
literature; as a result, it is probable we did not secure supplementary articles that may have illuminated additional information germane to our research. (5) Due to the novel presentation of SARS-CoV-2, source material was generally in short supply as there was a dearth of peer-reviewed studies to inform our search results.

\section{Conclusions}

Telemedicine has had a transformative impact on the provision of care in the era of COVID-19. It is evident from the presented research that the service lines covered are demonstrating nimble and effective responses to the COVID-19 outbreak through workflow adaptations via telemedicine within their respective care provisions. While general obstacles were encountered, which encompassed a lack of reimbursement parity, telemedicine infrastructure capabilities, regulatory and HIPAA compliance guidelines, lack of internet connectivity, and patient/provider discomfort with technology, each developed the capacity to accelerate telemedicine adoption to adjust to the needs of their patient populations by marshaling resources, expertise, and access. Since the SARS-CoV2 pandemic thrust telemedicine into uncharted territory, its capabilities continue to be refined as best practices are codified and datasets are assembled for utilization in future peer-reviewed publication dissemination. It behooves legislative and industry leaders to re-examine the benefits of telemedicine to remove barriers to its application not just in times of public health crises, but also for normal and customary clinical practice.

Author Contributions: Conceptualization, J.A.B., M.A.R., A.Z., J.R.B. and M.M.; methodology, J.A.B., M.A.R., A.Z., J.R.B. and M.M.; software, J.A.B., M.A.R., A.Z. and J.R.B.; validation, J.A.B., M.A.R., A.Z. and J.R.B.; formal analysis, J.A.B., M.A.R., A.Z. and J.R.B.; resources, M.A.R., A.Z. and J.R.B.; data curation, J.A.B., M.A.R., A.Z. and J.R.B.; writing - original draft preparation, J.A.B., M.A.R., A.Z. and J.R.B.; writing-review and editing, J.A.B., M.A.R., A.Z., J.R.B. and M.M.; visualization, J.A.B., M.A.R., A.Z. and J.R.B.; supervision, J.A.B. and M.M.; project administration, J.A.B. and M.M. All authors have read and agreed to the published version of the manuscript.

Funding: This research received no external funding.

Conflicts of Interest: The authors declare no conflict of interest.

\section{References}

1. Bashshur, R.; Shannon, G.W. History of Telemedicine: Evolution, Context, and Transformation; Mary Ann Liebert: New Rochelle, NY, USA, 2009.

2. Telemedicine: A Guide to Assessing Telecommunications in Health Care. Available online: https://www. ncbi.nlm.nih.gov/books/NBK45445/ (accessed on 25 July 2020).

3. The Evolution of Telemedicine. Available online: https://chironhealth.com/definitive-guide-to-telemedicine/ about-telemedicine/evolution-of-telemedicine/ (accessed on 26 July 2020).

4. Castro, F. The Roots of Telemedicine. Available online: https://athenetelehealth.com/the-roots-oftelemedicine/ (accessed on 26 July 2020).

5. Nesbitt, T.S.; Katz-Bell, J. History of Telehealth. In Understanding Telehealth; McGraw-Hill Education: New York, NY, USA, 2008.

6. Freiburger, G.; Holcomb, M.; Piper, D. The STARPAHC collection: Part of an archive of the history of telemedicine. J. Telemed. Telecare 2007, 13, 221-223. [CrossRef] [PubMed]

7. Opportunities and Barriers for Telemedicine in the United States during the COVID-19 Emergency and Beyond. Available online: https://www.kff.org/womens-health-policy/issue-brief/opportunities-and-barriers-fortelemedicine-in-the-u-s-during-the-covid-19-emergency-and-beyond/ (accessed on 26 July 2020).

8. Ludwig, S.; Zarbock, A. Coronaviruses and SARS-CoV-2: A Brief Overview. Anesthesia Analg. 2020, 131, 93-96. [CrossRef] [PubMed]

9. One in 10 Americans Use Telehealth, But Nearly 75\% Lack Awareness or Access, J.D. Power Finds. Retrieved. Available online: https://www.prnewswire.com/news-releases/one-in-10-americans-use-telehealth-butnearly-75-lack-awareness-or-access-jd-power-finds-300892939.html (accessed on 29 July 2020). 
10. The Impact of the COVID-19 Pandemic on Outpatient Visits: A Rebound Emerges. Available online: https://www.commonwealthfund.org/publications/2020/apr/impact-covid-19-outpatient-visits (accessed on 23 September 2020).

11. Nearly Half of Physicians Using Telehealth, up from Just 18\% in 2018. Available online: https://www. healthcareitnews.com/news/nearly-half-physicians-using-telehealth-just-18-2018 (accessed on 23 April 2020).

12. Survey: Physician Practice Patterns Changing as A Result Of COVID-19. Available online: https://link-galecom.libproxy.txstate.edu/apps/doc/A621578229/BIC?u=txshracd2550\&sid=BIC\&xid=c2c99c3c (accessed on 23 April 2020).

13. Telemedicine Options: The COVID-19 Pandemic Underscores the Role of Remote Patient Management. Podiatry Manag. 2020, 39, 79-80. Available online: https://eds-b-ebscohost-com.libproxy.txstate.edu/eds/ pdfviewer/pdfviewer?vid=1\&sid=c44ac7e7-793a-43d3-8dc5-842d219582de\%40sessionmgr101 (accessed on 23 April 2020).

14. Gondal, K.M.; Shaukat, S. Telemedicine in the Time of COVID-19 Pandemic. J. Coll. Phys. Surg. Pak. 2020, 30, 349-350. [CrossRef]

15. Reynolds, R. Telehealth in pregnancy. Lancet Diabetes Endocrinol. 2020, 8, 459-461. [CrossRef]

16. Machado, R.A.; De Souza, N.L.; Oliveira, R.M.; Júnior, H.M.; Bonan, P.R.F. Social media and telemedicine for oral diagnosis and counselling in the COVID-19 era. Oral Oncol. 2020, 105, 104685. [CrossRef]

17. COVID-19 Shuts Down Nation; Family Planning Need Not Stop. Available online: https://www.reliasmedia. com/articles/146022-covid-19-shuts-down-nation-family-planning-need-not-stop (accessed on 6 July 2020).

18. Canady, V.A. COVID-19 outbreak represents a new way of mental health service delivery. Ment. Heal. Wkly. 2020, 30, 1-4. [CrossRef]

19. Wu, C.; Liu, Y.; Ohannessian, R.; Duong, T.A.; Odone, A. Global Telemedicine Implementation and Integration Within Health Systems to Fight the COVID-19 Pandemic: A Call to Action. JMIR Public Health Surveill. 2020, 6, e18810. [CrossRef]

20. Telehealth: A New frontier in OB/GYN. Available online: https://www.contemporaryobgyn.net/view/ telehealth-new-frontier-obgyn (accessed on 6 September 2020).

21. COVID-19 Devastates At-Risk Populations. Available online: https://www.reliasmedia.com/articles/146066covid-19-devastates-at-risk-populations (accessed on 6 July 2020).

22. Romanick-Schmiedl, S.; Raghu, G. Telemedicine-Maintaining quality during times of transition. Nat. Rev. Dis. Prim. 2020, 6, 45. [CrossRef]

23. Vidal-Alaball, J.; Acosta-Roja, R.; Hernández, N.P.; Luque, U.S.; Morrison, D.; Pérez, S.N.; Llano, J.P.; Vèrges, A.S.; Seguí, F.L.; Pastor, N.; et al. Telemedicine in the face of the COVID-19 pandemic. Atención Primaria 2020, 52, 418-422. [CrossRef]

24. Wosik, J.; Fudim, M.; Cameron, B.; Gellad, Z.F.; Cho, A.; Phinney, D.; Curtis, S.; Roman, M.; Poon, E.G.; Ferranti, J.; et al. Telehealth transformation: COVID-19 and the rise of virtual care. J. Am. Med Inform. Assoc. 2020, 27, 957-962. [CrossRef] [PubMed]

25. Bashshur, R.; Doarn, C.R.; Frenk, J.M.; Kvedar, J.C.; Woolliscroft, J.O. Telemedicine and the COVID-19 Pandemic, Lessons for the Future. Telemed. e-Health 2020, 26, 571-573. [CrossRef] [PubMed]

26. Spinelli, A.; Pellino, G. COVID-19 pandemic: Perspectives on an unfolding crisis. Br. J. Surg. 2020, 107, 785-787. [CrossRef] [PubMed]

27. Mann, D.; Chen, J.; Chunara, R.; A Testa, P.; Nov, O. COVID-19 transforms health care through telemedicine: Evidence from the field. J. Am. Med Informatics Assoc. 2020, 27, 1132-1135. [CrossRef]

28. Aziz, A.; Zork, N.; Aubey, J.J.; Baptiste, C.D.; D’Alton, M.E.; Emeruwa, U.N.; Fuchs, K.M.; Goffman, D.; Gyamfi-Bannerman, C.; Haythe, J.H.; et al. Telehealth for High-Risk Pregnancies in the Setting of the COVID-19 Pandemic. Am. J. Perinatol. 2020, 37, 800-808. [CrossRef]

29. Zhou, X.; Snoswell, C.L.; Harding, L.E.; Bambling, M.; Edirippulige, S.; Bai, X.; Smith, A.C. The Role of Telehealth in Reducing the Mental Health Burden from COVID-19. Telemed. e-Health 2020, 26, 377-379. [CrossRef]

30. Freeman, M.P. COVID-19 From a Psychiatry Perspective: Meeting the Challenges. J. Clin. Psychiatry $2020,81$. [CrossRef]

31. Shift to Telehealth Could Remain Trend After COVID-19. Available online: https://www.reliasmedia.com/ articles/146176-shift-to-telehealth-could-remain-trend-after-covid-19 (accessed on 22 June 2020). 
32. Knopf, A. Telepsychiatry coming into its own with COVID-19. Brown Univ. Child Adolesc. Psychopharmacol. Child Adolesc. Psychopharmacol. Updat. 2020, 22, 1-3. [CrossRef]

33. Parikh, A.; Kumar, A.A.; Jahangir, E. Cardio-Oncology Care in the Time of COVID-19 and the Role of Telehealth. JACC CardioOncol. 2020, 2, 356-358. [CrossRef]

34. Rodler, S.; Apfelbeck, M.; Stief, C.; Heinemann, V.; Casuscelli, J. Lessons from the coronavirus disease 2019 pandemic: Will virtual patient management reshape uro-oncology in Germany? Eur. J. Cancer 2020, 132, 136-140. [CrossRef]

35. Steingass, S.K.; Maloney-Newton, S. Telehealth Triage and Oncology Nursing Practice. Semin. Oncol. Nurs. 2020, 36, 151019. [CrossRef] [PubMed]

36. Hospitals Use Telemedicine to Limit Exposures, Preserve PPE, Guide Patients to Right Setting. Available online: https://www.reliasmedia.com/articles/146050-hospitals-use-telemedicine-tolimit-exposures-preserve-ppe-guide-patients-to-right-setting (accessed on 22 June 2020).

37. Jnr, B.A. Use of Telemedicine and Virtual Care for Remote Treatment in Response to COVID-19 Pandemic. J. Med Syst. 2020, 44, 1-9. [CrossRef]

38. Portnoy, J.M.; Waller, M.; Elliott, T. Telemedicine in the Era of COVID-19. J. Allergy Clin. Immunol. Pract. 2020, 8, 1489-1491. [CrossRef]

39. Contreras, C.M.; Metzger, G.A.; Beane, J.D.; Dedhia, P.H.; Ejaz, A.; Pawlik, T.M. Telemedicine: Patient-Provider Clinical Engagement During the COVID-19 Pandemic and Beyond. J. Gastrointest. Surg. 2020, 24, 1-6. [CrossRef] [PubMed]

40. Boxer, R.J.; Ellimoottil, C. Advantages and utilization of telemedicine. mHealth 2019, 5, 12. [CrossRef] [PubMed]

41. Jobes, D.A.; Crumlish, J.A.; Evans, A.D. The COVID-19 pandemic and treating suicidal risk: The telepsychotherapy use of CAMS. J. Psychother. Integr. 2020, 30, 226-237. [CrossRef]

42. Elkaddoum, R.; Haddad, F.G.; Eid, R.; Kourie, H.R. Telemedicine for cancer patients during COVID-19 pandemic: Between threats and opportunities. Future Oncol. 2020, 16, 1225-1227. [CrossRef]

43. Trinidad, J.; Kroshinksy, D.; Kaffenberger, B.H.; Rojek, N. Telemedicine for inpatient dermatology consultations in response to the COVID-19 pandemic. J. Am. Acad. Dermatol. 2020, 83, e69-e71. [CrossRef]

44. Incorporating telemedicine as part of COVID-19 outbreak response systems. Am. J. Manag. Care 2020, 26, 147-148. [CrossRef]

45. Teledermatology and HIPAA Compliance in the Era of COVID-19. Available online: dermatologytimes.com/ view/teledermatology-and-hipaa-compliance-era-covid-19 (accessed on 22 June 2020).

46. Prasad, A.; Brewster, R.; Newman, J.G.; Rajasekaran, K. Optimizing your telemedicine visit during the COVID-19 pandemic: Practice guidelines for patients with head and neck cancer. Head Neck 2020, 42, 1317-1321. [CrossRef]

47. Badeli, H.; Nejad, A.T.; Rad, A.H. Utilizing Telemedicine for Managing COVID-19. J. Pediatr. Nephrol. 2020, 8. [CrossRef]

48. Cosic, K.; Popovic, S.; Sarlija, M.; Kesedzic, I. Impact of Human Disasters and COVID-19 Pandemic on Mental Health: Potential of Digital Psychiatry. Psychiatr. Danub. 2020, 32, 25-31. [CrossRef] [PubMed]

(C) 2020 by the authors. Licensee MDPI, Basel, Switzerland. This article is an open access article distributed under the terms and conditions of the Creative Commons Attribution (CC BY) license (http://creativecommons.org/licenses/by/4.0/). 